\title{
INFLUENCE OF AN INTERVENTION PROGRAMME ON KNOWLEDGE OF HEALTH AMONG SCHOOL CHILDREN IN MANGALORE CITY.
}

\author{
Prof. AshaRai. M. G. \\ $\mathrm{Ph}$. D Research Scholar, Associate professor \\ HOD. Home Science, Besant Women's College. Mangalore, India
}

Dr. Mamatha. B

Research Guide, Associate professor,

Department of Resource Management, Smt. V.H.D. Central Institute of Home Science, Bangalore, India

\begin{abstract}
Health is a prime factor in an individual's life. Good health is a priceless blessing in life. It is truly said that, of all things in the world health is the most valuable that one can possess. The famous saying Health is Wealth highlights the importance of good health in our life. Knowledge on health helps in preventing many communicable diseases and benefits the children to enjoy a healthy and productive school life. This study was undertaken to find the knowledge on health among school children in Mangalore city and to know the influence of intervention programme on health among them.

Tools used for the study were survey and questionnaire. Sample of 82 children in the age range 10-12 years were taken for the study. A survey was conducted to assess the knowledge on health of children of Mangalore city. Two schools of which one Government and one Aided were selected. After the pretest intervention was administered to 52 children of Aided school and 30 children of Government school. After the intervention, questionnaires were distributed to find the influence of intervention. Data collected by using the questionnaire were scored and tabulated. The enhancement of knowledge from pre-test to post test was found to be 37.5percent on health.
\end{abstract}

Key words: Knowledge, Health, Government school, Aided school, Intervention.

Cite this Article: Prof. AshaRai. M. G. and Dr. Mamatha. B, Influence of an Intervention Programme on Knowledge of Health among School Children in Mangalore City, International Journal of Advanced Research in Engineering and Technology, 10(1), 2019, pp 154-159.

http://iaeme.com/Home/issue/IJARET?Volume $=10 \&$ Issue $=1$ 


\section{INTRODUCTION}

Every human being is the author of his own health and disease. So, we should learn and teach our children to maintain better health. The World health organization (WHO) defined health as "a state of complete physical, mental, and social well-being and not merely the absence of disease or infirmity"(Health Wikipedia).This clearly imply the need for promoting the holistic wellbeing and comprehensive healthcare that enables people to increase control over improving their own health. Incorporating health promotion mechanisms at every level of our system is essential (Sa Janellede, 2015). The purpose of health education is to positively influence the health behavior of individuals and communities as well as the living and working conditions that influence their health.

Health education builds student's knowledge, skills, and positive attitudes about health. Health education teaches about physical, mental, emotional and social health. It motivates students to improve and maintain their health, prevent disease, and reduce risky behaviours. Health education promotes learning in other subjects. Healthy students learn better. Numerous studies have shown that healthier students tend to do better in school. They have higher attendance, have better grades, and perform better on tests.

This study is undertaken by the investigator to find the knowledge on health and the influence of intervention programme on health among school children in Mangalore city.

\section{METHODOLOGY}

\section{Aim}

The study aimed at finding out the Influence of an intervention programme on knowledge of health among school children in Mangalore city.

\section{Objectives:}

1. To know the existing knowledge of school children on health.

2. To find the Influence of an intervention programme on knowledge of health among school children in Mangalore city.

\subsection{Research Design:}

Two schools were identified for conducting the intervention programme. One Government school and one Aided school were selected as these children found to have less knowledge on health. Children aged 10-12 years studying in V, VI and VII standards from Government (30) and Aided (52) a total of 82 were drawn as samples for the intervention programme. Based on the inputs after administering the questionnaire, an intervention module was systematically developed for children to enhance their knowledge on health. Intervention was administered for one academic year.

\section{ANALYSIS OF THE DATA:}

\subsection{Background information:}

Intervention Programme was administered to respondents of Government (30) and Aided school (52) children after conducting the pre-test. Most of the children were of 12 and 11 years. Children studying in VI standard were more when compared to V and VII standard students. Girl students were more than boys. Majority of the students belonged to Kannada speaking Hindu nuclear families. Most of the children were nonvegetarians. Higher percentages of the 
respondents were from the income range Rs.12897-17196. Considerable percentages of the respondent's mothers were Illiterate followed by a Primary level of education. Higher percentages of the respondents' fathers and mothers were commission agents, brokers.

TABLE - 1: Classification of Respondents by Anthropometric measurements

\begin{tabular}{|c|c|c|c|c|c|c|c|c|}
\hline \multirow{3}{*}{ Characteristics } & \multirow{3}{*}{ Category } & \multicolumn{6}{|c|}{ Respondents } & \multirow{3}{*}{$\begin{array}{c}\chi^{2} \\
\text { Test }\end{array}$} \\
\hline & & \multicolumn{2}{|c|}{ Government } & \multicolumn{2}{|c|}{ Aided } & \multicolumn{2}{|c|}{ Combined } & \\
\hline & & $\mathrm{N}$ & $\%$ & $\mathrm{~N}$ & $\%$ & $\mathrm{~N}$ & $\%$ & \\
\hline \multirow{3}{*}{ Height (cm) } & $100-127$ & 6 & 20.0 & 22 & 42.3 & 28 & 34.1 & \multirow{3}{*}{$5.82^{\mathrm{NS}}$} \\
\hline & $138-140$ & 16 & 53.3 & 15 & 28.9 & 31 & 37.8 & \\
\hline & $141-160$ & 8 & 26.7 & 15 & 28.8 & 23 & 28.1 & \\
\hline \multirow{3}{*}{ Weight (kg) } & $20-26$ & 11 & 36.7 & 22 & 42.3 & 33 & 40.2 & \multirow{3}{*}{$0.40^{\mathrm{NS}}$} \\
\hline & $27-33$ & 11 & 36.7 & 19 & 36.5 & 30 & 36.6 & \\
\hline & $34-50$ & 8 & 26.6 & 11 & 21.5 & 19 & 23.2 & \\
\hline \multirow{2}{*}{$\begin{array}{c}\text { Body mass } \\
\text { index (BMI) }\end{array}$} & Malnourished & 24 & 80.0 & 40 & 76.9 & 64 & 78.1 & \multirow{2}{*}{$0.11^{\mathrm{NS}}$} \\
\hline & Normal & 6 & 20.0 & 12 & 23.1 & 18 & 21.9 & \\
\hline Total & & 30 & 100.0 & 52 & 100.0 & 82 & 100.0 & \\
\hline
\end{tabular}

Table-1indicates the classification of respondents by anthropometric measurement. The results show that higher percentage $(37.8 \%)$ of the respondents were in the height range of 138$140 \mathrm{~cm}$ followed by 34.1 percent were in the height range of $100-127 \mathrm{~cm}$ and 28.1 percent of the respondents were in the height range of 141-160 $\mathrm{cm}$. However, the height and the anthropometric measurement was found to be statistically non-significant $\left(\chi 2=5.82^{\mathrm{NS}}\right)$.

The results depict that 40.2 percent of the respondents were in the weight range of $20-26 \mathrm{~kg}$ followed by 36.6 percent were in the weight range of $27-33 \mathrm{~kg}$ and 23.2 percent of the respondents were in the weight range of $34-50 \mathrm{~kg}$. Further, the weight and the anthropometric measurement was found to be statistically non-significant $\left(\chi 2=0.40^{\mathrm{NS}}\right)$.

The result shows that the majority $(78.1 \%)$ of the respondents were malnourished and only 21.9 percent were Normal. However, the body mass index and respondents of different school were found to be statistically non-significant $\left(\chi 2=0.11^{\mathrm{NS}}\right)$.

TABLE - 2: Overall mean knowledge scores of Respondents on Health

\begin{tabular}{|c|c|c|c|c|c|}
\hline \multirow{2}{*}{ Aspects } & \multicolumn{4}{|c|}{ Knowledge Scores } & \multirow{2}{*}{$\begin{array}{c}\text { Paired } \\
\text { 't' } \\
\text { Test }\end{array}$} \\
\hline Pre test & Mean & SD & $\begin{array}{c}\text { Mean } \\
(\%)\end{array}$ & $\begin{array}{c}\text { SD } \\
(\%)\end{array}$ & \\
\hline Post test & 21.1 & 2.1 & 42.2 & 4.3 & \multirow{2}{*}{$28.06^{* *}$} \\
\hline Enhancement & 18.8 & 6.0 & 79.6 & 12.1 & \\
\hline
\end{tabular}

$* *$ Significant at $1 \%$ level, $\quad$ Statements $=50$, Max. Score $=50$

Table-2 reveals the overall mean knowledge scores of respondents on health. It was seen from the finding that the overall pre-test mean knowledge scores were found to be 42.2 percent as compared to post-test knowledge scores $(79.6 \%)$ towards health. Further, the enhancement of knowledge from pre-test to post test was found to be 37.5 percent on health. The data subjected for statistical test reveals the enhancement of knowledge and was found to be highly significant $\left(\mathrm{t}=28.06^{* *}\right)$. 
Influence of an Intervention Programme on Knowledge of Health among School Children in Mangalore City

TABLE - 3: Mean Knowledge scores of Respondents on Health by Type of school

\begin{tabular}{|c|c|c|c|c|c|c|c|}
\hline \multirow[b]{2}{*}{ Type of school } & \multirow[b]{2}{*}{$\begin{array}{l}\text { Sample } \\
\text { (n) }\end{array}$} & \multirow[b]{2}{*}{ Aspects } & \multicolumn{4}{|c|}{ Knowledge Scores } & \multirow{2}{*}{$\begin{array}{c}\text { Paired } \\
\text { ' } \mathrm{t} \text { ' } \\
\text { Test }\end{array}$} \\
\hline & & & Mean & $\mathrm{SD}$ & $\begin{array}{c}\text { Mean } \\
(\%)\end{array}$ & $\begin{array}{r}\text { SD } \\
(\%)\end{array}$ & \\
\hline \multirow{3}{*}{ Government } & \multirow{3}{*}{30} & Pre test & 20.2 & 1.9 & 40.3 & 3.8 & \multirow{3}{*}{$15.11^{* *}$} \\
\hline & & Post test & 38.5 & 6.3 & 77.0 & 12.5 & \\
\hline & & Enhancement & 18.3 & 6.7 & 36.7 & 13.3 & \\
\hline \multirow{3}{*}{ Aided } & \multirow{3}{*}{52} & Pre test & 21.6 & 2.1 & 43.2 & 4.2 & \multirow{3}{*}{$23.97 * *$} \\
\hline & & Post test & 40.6 & 5.8 & 81.2 & 11.6 & \\
\hline & & Enhancement & 19.0 & 5.7 & 37.9 & 11.4 & \\
\hline
\end{tabular}

$* *$ Significant at $1 \%$ level, $\quad$ Statements $=50$, Max. Score $=50$

Table 3 reveals the overall mean knowledge score of respondents on health by type of schools. It was seen from the finding that pretest knowledge score was found to be 40.3 percent as compared to posttest knowledge score $(77.0 \%)$ towards health by Government schools. Further, the mean enhancement of knowledge from pre-test to post test was found to be 36.7percent. The data subjected for statistical test reveals the enhancement of knowledge and was found to be statistically highly significant $\left(\mathrm{t}=15.11^{* *}\right)$.

It was seen from the finding that pretest knowledge score was found to be 43.2 percent as compared to posttest knowledge score 81.2 percent towards health by Aided schools. Further, the mean enhancement of knowledge from pre-test to post test was found to be 37.9 percent. The data subjected for statistical test reveals the enhancement of knowledge was found to be statistically highly significant $(\mathrm{t}=23.97 * *)$.

TABLE -4: Respondents Pretest and Post-test Knowledge level on Health

\begin{tabular}{|c|c|c|c|c|c|}
\hline \multirow{3}{*}{ Knowledge level } & \multicolumn{4}{|c|}{ Respondents } & \multirow{3}{*}{$\begin{array}{c}\chi^{2} \\
\text { Test }\end{array}$} \\
\hline & \multicolumn{2}{|c|}{ Pre-test } & \multicolumn{2}{|c|}{ Post-test } & \\
\hline & $\mathrm{N}$ & $\%$ & $\mathrm{~N}$ & $\%$ & \\
\hline Inadequate $(<50)$ & 79 & 96.3 & 0 & 0.0 & \multirow{3}{*}{$152.82 *$} \\
\hline Moderate(51-75) & 3 & 3.7 & 41 & 50.0 & \\
\hline Adequate $(>75)$ & 0 & 0.0 & 41 & 50.0 & \\
\hline Total & 82 & 100.0 & 82 & 100.0 & \\
\hline
\end{tabular}

* Significant at 5\% Level, $\chi 2(0.05,2 \mathrm{df})=5.991$

Table- 4 reveal the pre-test and posttest knowledge level of the respondents on health. The findings show that in the pretest, the majority of the respondents $(96.3 \%)$ were found to have inadequate knowledge level on health as compared to 3.7 percent of the respondents with moderate knowledge level. After the intervention programme, it was found that 50 percent of the respondents had moderate and adequate knowledge level. However the respondent's knowledge level between pretest and post-test was found to be highly significant $(\chi 2=152.82 *)$ revealing the effectiveness of an intervention programme. 
TABLE 5 Association between Food habit and Health problems and Post-test Knowledge level on Health

\begin{tabular}{|c|c|c|c|c|c|c|c|c|}
\hline \multirow{4}{*}{ Characteristics } & & & & & & & & $\mathrm{N}=82$ \\
\hline & \multirow{3}{*}{ Category } & \multirow{3}{*}{$\begin{array}{l}\text { Sample } \\
\text { (n) }\end{array}$} & \multicolumn{4}{|c|}{ Knowledge Level } & \multirow{3}{*}{$\begin{array}{l}\chi^{2} \\
\text { Value }\end{array}$} & \multirow{3}{*}{$\begin{array}{l}\mathrm{P} \\
\text { Value }\end{array}$} \\
\hline & & & \multicolumn{2}{|c|}{ Moderate } & \multicolumn{2}{|c|}{ Adequate } & & \\
\hline & & & $\mathrm{N}$ & $\%$ & $\mathrm{~N}$ & $\%$ & & \\
\hline \multirow[b]{2}{*}{ Food habit } & Vegetarian & 20 & 14 & 70.0 & 6 & 30.0 & \multirow[b]{2}{*}{$4.23 *$} & \multirow[b]{2}{*}{$\mathrm{P}<0.05$} \\
\hline & $\begin{array}{l}\text { Non } \\
\text { vegetarian }\end{array}$ & 62 & 27 & 43.6 & 35 & 56.4 & & \\
\hline \multirow{4}{*}{ Eat outside food } & Always & 7 & 5 & 71.4 & 2 & 28.6 & \multirow{4}{*}{$\begin{array}{l}1.49 \\
\text { NS }\end{array}$} & \multirow{4}{*}{$\mathrm{P}>0.05$} \\
\hline & Some times & 29 & 14 & 48.3 & 15 & 51.7 & & \\
\hline & Rarely & 39 & 19 & 48.7 & 20 & 51.3 & & \\
\hline & Never & 7 & 3 & 42.9 & 4 & 57.1 & & \\
\hline \multirow{2}{*}{$\begin{array}{l}\text { Previous health } \\
\text { problems }\end{array}$} & No & 66 & 32 & 48.5 & 34 & 51.5 & \multirow{2}{*}{$\begin{array}{l}0.31 \\
\text { NS }\end{array}$} & \multirow{2}{*}{$\mathrm{P}>0.05$} \\
\hline & Yes & 16 & 9 & 56.3 & 7 & 43.7 & & \\
\hline \multirow{2}{*}{ Stomach ache } & No & 15 & 11 & 73.3 & 4 & 26.7 & \multirow{2}{*}{$4.00 *$} & \multirow{2}{*}{$\mathrm{P}>0.05$} \\
\hline & Yes & 67 & 30 & 44.8 & 37 & 55.2 & & \\
\hline Combined & & 82 & 41 & 50.0 & 41 & 50.0 & & \\
\hline
\end{tabular}

* Significant at 5\% Level,

NS: Non-significant

Table 5 depicts the association between food habit, health problems and post-test knowledge level on health. It was evident from the findings that a higher percentage of nonvegetarian respondents (56.4\%) were found to have adequate knowledge on health as compared to vegetarian respondents (Figure-50). However the association between the type of food habit and knowledge level was found to be statistically significant $\left(\chi 2=4.23^{*}, \mathrm{p}<0.05\right)$.

A higher percentage of respondents $(57.1 \%)$ who never eat outside food found to have adequate knowledge as compared to respondents who eat outside sometimes $(51.7 \%)$, who eat rarely $(51.3 \%)$ and who eat outside always $(28.6 \%)$. However the association between their eating and knowledge level was found to be non-significant $(\chi 2=1.49, \mathrm{p}>0.05)$.

A higher percentage of respondents $(51.5 \%)$ with no health problems previously found to have adequate knowledge level as compared to respondents $(43.7 \%)$ with previous health problems. The association between previous health problems and knowledge level was found to be non-significant. $(\chi 2=0.31, \mathrm{p}>0.05)$.

It could be inferred that 73.3 percent of the respondents having moderate knowledge on health did not complain of stomach ache. However, 52.2percent having adequate and 44.8 percent having moderate knowledge on health complained of frequent stomach ache (Figure51). Chi-square analysis also substantiated the findings by statistically significant score $\left(\chi 2=4.00^{*}, \mathrm{p}<0.05\right)$.

\section{CONCLUSION}

It can be concluded from the present study that there was enhancement of knowledge on health among school children after the intervention programme. 
Influence of an Intervention Programme on Knowledge of Health among School Children in Mangalore City

\section{REFERENCES}

[1] Sa Janellede (2015), "Health Promotion-Rethinking Our Disease Control Strategy" Institute of public health Bengaluru.

[2] Sang Young Lee, U-Health System for Correct Walking Posture, International Journal of Mechanical Engineering and Technology, 9(11), 2018, pp. 922- 926.

[3] Health: Wikipedia, the free Encyclopedia. Https: //en. wikipedia. org/ wiki/ Health

[4] K. Govindarajulu and Dr. D. Venkataramaraju, Knowledge Management Practices and Performance Enhancement of Employees in the Software Industry, International Journal of Civil Engineering and Technology, 9(12), 2018, pp. 612-618

[5] Shaik Kamruddin and Md. Wasim Akram. Knowledge Management Practices in Information Technology Sector in India: A Study. International Journal of Management, 7(2), 2016, pp. 652 -662 .

[6] C.Ramanigopal, Knowledge Management Strategies in Higher Education, International Journal of Advanced Research in Management (IJARM), Volume 3, Issue 1, January- June (2012), pp. 20-29.

[7] Rajendra S.Pujari, Dr.Pallavi P Jamsendekar and Dr.Rajesh Kanthe, Knowledge Management System a Panacea for Rural Public Administration, International Journal of Management (IJM), Volume 4, Issue 2, March- April (2013), pp. 180-187. 